Fecha de recepción: abril 2019 Fecha de aceptación: octubre 2019 Versión final: diciembre 2019

\section{Leyendo la realidad desde el cine. Imagen femenina y juventud en los últimos films de Pedro Almodóvar}

Mónica Gruber *

\begin{abstract}
Resumen: Los tiempos posteriores a la muerte del general Franco en España se caracterizaron por el destape. A todas luces aquello prohibido por el régimen durante tantos años irrumpiría en la vida cotidiana y no tardaría en verse plasmado en la pantalla cinematográfica. De este modo, mostrar y decir todo lo anteriormente excluido y prohibido se transformó en la clave de bóveda de muchas de las creaciones culturales de ese momento. Los '80 saludarían la Movida madrileña, sitio de reunión forzosa para el ambiente artístico. Pedro Almodóvar sería uno de sus integrantes. Sin formación académica cinematográfica, rápidamente se convirtió en uno de los referentes del joven cine español. Luego de una etapa manifiestamente provocativa, su cine alcanzó una madurez formal coincidente con su proyección internacional. De este modo, ingresa en el mercado estadounidense y latinoamericano, cosechando nominaciones, premios y reconocimiento.

Definido por algunos autores como el cineasta que mejor representa a las mujeres, consideramos que sus películas plasman una visión altamente personal del alma femenina. Desembarazado de los estereotipos propios de los medios de comunicación y del franquismo, manifiesta en su obra una construcción plural de la imagen del "sexo débil" y de la juventud. Nos proponemos en este trabajo analizar sus últimas realizaciones fílmicas -Los abrazos rotos (2009), La piel en que habito (2011) y Julieta (2016)- para reflexionar acerca de las mujeres que pueblan sus encuadres, el modo en que representa a los jóvenes y sus problemáticas, así como los motivos de este particular tratamiento formal y estético. Esto nos lleva a preguntarnos si consideramos la existencia de un "estilo Almodóvar".
\end{abstract}

Palabras clave: cine - representación - imagen femenina - juventud - autor.

[Resúmenes en inglés y portugués en las páginas 60-61]

${ }^{(*}$ Es Licenciada y Profesora en Artes, de la U.B.A. donde se desempaña como Adjunta en La Literatura en las Artes Combinadas I (FADU) y Ayudante Regular (Artes - F. y L.). Es Profesora de Arte y Literatura (en la UMSA), del Seminario de Medios de Comunicación (UTN), de Discurso Audiovisual II (Historia del Cine, en la UP). Codirige Proyecto SI titulado "Los mitos en las artes audiovisuales: pervivencia y resemantización" (Código PIA HyC-11) - F.A.D.U. - U.B.A. Produjo material didáctico para la Universidad Tecnológica Nacional. Ha participado en Congresos Nacionales e Internacionales de Cine, Teatro, Literatura e Historia. Tiene publicados trabajos sobre el campo de las Artes en volúmenes de EUDEBA, de la Academia Nacional de Ciencias de Bs. As; en revistas especializadas, entre ellas, Itinerarios y Tipográfica. 


\section{Almodóvar antes de ser Almodóvar ${ }^{1}$}

Nació en Calzada de Calatrava, La Mancha, el 25 de septiembre de 1951. Vino al mundo en una familia de clase media baja dedicada a las tareas rurales y sin grandes aspiraciones: no era mucho lo que esperaba el matrimonio Almodóvar de la vida para sus cuatro hijos. Ocho años después su familia decide trasladarse a Cáceres. La subsistencia en las aldeas era difícil y las esperanzas escasas por aquellos duros años.

Pedro amaba la música, tenía muy buena voz y esto fue una bendición ya que le permitió acceder a una beca para cursar el Bachillerato. Sus padres soñaban con que tomara los hábitos, por lo que le hicieron cursar estudios religiosos. Sin embargo, los sueños del joven divergirían del mandato familiar.

La influencia del Mayo francés (1968) y del movimiento Hippie entró en la Península Ibérica pese a las estrategias de resistencia del gobierno franquista.

A los diecisiete años el joven se traslada a Madrid. Por ese entonces descubría su pasión por el cine que no abandonaría el resto de su vida. En lo referente a la política, Franco había clausurado la Escuela de Cine. Pedro debería conseguir un trabajo para solventar su vida, es así como se convertiría en empleado de la empresa Telefónica de España.

En la capital toma contacto con el $\operatorname{cine}^{2}$ y la literatura. Experimenta una independencia desconocida hasta entonces y crea nuevos lazos afectivos y amorosos.

Viaja a Inglaterra. En Londres halla una libertad intelectual y sexual única. Conocido por muchos, devenido en provocador y con una alta dosis de simpatía se convierte rápidamente en el centro de atención de las fiestas.

De regreso a su país compra con sus ahorros una cámara de Súper 8 con la que filma sus primeros cortos fuertemente influenciado por la estética "pop".

El cine español seguía, sin embargo, maniatado y amordazado por una fuerte censura local. La muerte de Franco, en 1975, trajo aparejada una ola de destape: el desnudo y el sexo arrastraron grandes masas de espectadores a los cines. También trajo una libertad desconocida. En un intento de visualizar todo el material cinematográfico prohibido en vida del Generalísimo el público tuvo acceso a producciones diversas para satisfacer "el hambre visual sexual"3 que también tenía su correlato en el boom de consumo de revistas pornográficas y eróticas.

Mientras tanto Pedro formó parte del grupo de teatro Los Goliardos, donde conoció a la actriz Carmen Maura, quien le prestaría el dinero para filmar su primer largometraje. Además, trabajó como extra en cine y teatro y escribió fotonovelas. La calle y la noche se convertirían en su escuela.

Los cortos en Súper 8 que filmaba los presentaba en espacios que albergaban múltiples disciplinas artísticas, tal como evoca el fundador de la revista libertaria Ajoblanco:

[...] Un hombre bocadillo paseando por las Ramblas con un cartel colgando que anunciaba el pase de los cortos en Magic. Los títulos: Film político, Historia de amor que termina en boda, La caída de Sodoma, Sexo va sexo viene y El sueño. [...] Observábamos perplejos cómo, en un espacio no muy grande, Pedro Almodóvar pasaba entre empujones sus películas en Súper 8 mediante un proyector aficionado. Él mismo, sin micrófono, narraba algunos diálogos y 
cantaba las coplas de Piquer y de otras cupleteras con un chorro de voz engolada (Ribas, 2007, pp. 407-408).

La muerte del Caudillo supuso cambios políticos y sociales producto de la finalización de un largo y duro gobierno y la transición hacia la democracia. Con todo, existió un marcado rechazo a la militancia política y la oposición que supuso el período anterior. Entre 1978 y $1985^{4}$ se desarrolla en Madrid la denominada "movida" y, tal como señalamos en otro lugar:

No hemos encontrado una unívoca definición del término [...] pues distintos autores coinciden en mencionar la vaguedad del mismo y su polisemia. Siendo considerado un fenómeno underground y minoritario. [...] Las ideas del pop de Andy Warhol, la expresividad del punk, el redescubrimiento de formas urbanas populares rechazadas por las corrientes progresistas durante el franquismo, que las consideraba marginales y alienadas, serán rasgos fundamentales de este movimiento. Es necesario no perder de vista que se trataba de un grupo de gente joven, con inquietudes intelectuales y artísticas, cuyo principal objetivo era vivir el presente (Balán y Gruber, 2009, pp. 3-4).

Teresa Vilarós señala que en ese momento la movida madrileña se centra en la ruina, el exceso, y la muerte (Balán y Gruber, 2009, p. 4). Es por ello que en el cine de Almodóvar de la primera etapa lo revulsivo y provocador se convierte en la marca del orillo como forma de exorcizar el oscurantismo y la censura franquista. Así, según confesase el director en una entrevista, su mayor venganza fue ignorar a Franco, borrarlo como si nunca hubiese existido (Strauss, 2001, s.d.).

La movida implicaba la libertad sexual e individual, así como la falta de compromiso. Al mismo tiempo, no deberíamos perder de vista la importancia que cobraron las drogas para dicho grupo, tema que aparecerá retratado en varios de sus films. Así pues, la búsqueda expresiva se vuelca a diversos campos artísticos: la música, el cine, el comic, el diseño, la fotografía, la plástica y la moda.

Hemos demarcado en un trabajo anterior que consideramos:

[...] Dos etapas en la filmografía de Almodóvar, la primera de las cuales termina con La ley del deseo (1986), período que refleja fielmente los contenidos, modos de expresión y deseos de la Movida, de la que Almodóvar es uno de los representantes más conocidos: esta primera época estuvo "muy marcada por la provocación y la vulgaridad" siendo "voluntariamente excesiva y provocadora" (Méjan, 2007, s.d.). La segunda se extiende hasta sus últimas producciones. En este momento, su estética, temática y lenguaje cinematográfico se modifican dejando de ser exclusivamente provocadores (Balán y Gruber, 2010, p. 3).

Pepi, Luci, Bom y otras chicas del montón (1980), Laberinto de pasiones (1982) y Entre tinieblas (1983) se alzan de este modo como fieles exponentes de la "movida", por tal motivo no debe extrañarnos que lo escatológico forme parte de ellas 5 . 
Predominan en este momento mayoritariamente personajes femeninos. Sin juzgarlas ni apiadarse de ellas Almodóvar les otorga un sitio privilegiado en la pantalla. Ninguna de ellas falta. Todas y cada una de ellas están presentes: madres e hijas, drogadictas, travestis, transexuales... Ya que, tal como afirmamos:

En la filmografía de Almodóvar predominan los roles femeninos. Cabe aclarar por qué en esta primera instancia hablamos de roles femeninos y no de mujeres, ya que consideramos también femeninos los protagonizados por travestis y transexuales. Según nuestro criterio: todas son mujeres (Balán y Gruber, 2009, p. 4).

Con respecto a las féminas de Almodóvar nada parece escandalizarlas. Hacen uso de formas de lenguaje que no eran representativas del léxico cotidiano por no considerarse adecuadas para el uso femenino de la época. Se trata de personajes lineales, desinhibidos, expeditivos y gregarios (Gruber y Balán, 2009, 2010).

Puntualizamos que en estos films el sexo se halla siempre presente. No se trata de una visión con matices pornográficos o exhibicionistas, sino que, por el contrario, se manifiesta permanentemente en los diálogos o en la imaginación. ¿Producto de la época? Creemos que es la visión y el reflejo de lo que Almodóvar quería comunicar. De este modo, el ideario de la movida, el camp, el pop estadounidense y una estética del exceso, sumado a su visión personal dieron como resultado un estilo distintivo que generó rechazo en España y aceptación en el extranjero. Una vez más confirmamos con ello que nadie es profeta en su tierra.

\section{Almodóvar: el reconocimiento y la fama}

Los films del período posterior reflejan un cambio técnico, narrativo y estético. Dejan de ser provocadores si bien conservan algunos matices transgresores.

De la mano de Mujeres al borde de un ataque de nervios (1988) llega el reconocimiento nacional e internacional. La candidatura a los premios Óscar le abriría las puertas. De la periferia al centro de la sociedad, este cine se afianzaba en el corazón de España. Brito García analiza las operaciones que se realizan en estos casos de movilidad y cambio al enfatizar:

Pero, a veces, el propio sistema asume el papel de crear y de dirigir la cultura del subgrupo disidente, a fin de dotarlo de una personalidad por lo menos manejable, y rentable". En tales casos la subcultura del sector marginado es mediatizada por el sector marginante. Lejos de ser afirmación de la diferencia y factor de oposición a lo establecido, termina por consistir en un conjunto de satisfacciones sustitutivas, mediante las cuales el marginado suaviza su desacuerdo con la cultura oficial y, en última instancia, halla su posible funcionamiento dentro de ella. La subcultura de la disidencia se transforma en subcultura del consumo (1990, pp. 8-9).

Muchos premios saludaron la trayectoria del director a partir de ese momento, sin embargo, el Óscar llegaría un poco más tarde, en 1999 con Todo sobre mi madre, consagrada 
como la mejor película de habla no inglesa. Años después, sería el turno del mejor guion original con Hable con ella (2002).

Consideramos Matador (1986) como un punto de inflexión ya que la elección de la paleta cromática se trasladaría de aquí en más al resto de los films del director manchego, constituyéndose, de este modo, en característica de su estilo.

Las mujeres de esta fase no presentan diferenciación en los usos del lenguaje ya se trate de heterosexuales, lesbianas, transexuales o travestis (Balán y Gruber, 2010, pp. 4-5).

$\mathrm{Si}$ algo parece caracterizar el universo almodovariano son las mujeres. Todas forman parte de él, sufren, luchan, "son profundamente gregarias, se ayudan, son cómplices, se consuelan, no se critican" (Balán y Gruber, 2010, p. 4). De este modo, presentan particularidades que, en definitiva, parecen ser propias de los hombres.

En cuanto a los temas que aborda el director, recordemos que:

El asesinato es una forma aceptada para resolver los conflictos en este universo fílmico, matan por venganza, en defensa propia, por codicia y celos. Cuando el asesinato es cometido por un personaje femenino queda impune. [...] Sin embargo, los crímenes que ellas cometen no se juzgan, ni acarrean problemas de conciencia (Balán y Gruber, 2010, p. 5).

A nivel de lenguaje cinematográfico la madurez se torna evidente, sin estridencias ni innovaciones, por el contrario, desarrollando una gran habilidad técnica y narrativa.

\section{De Los abrazos rotos a Julieta}

Para analizar estas películas nos proponemos trazar un eje asociativo entre Los abrazos rotos (2009), La piel en que habito (2011) y Julieta (2016) dado el tono y el carácter que presentan. En el caso de La concejala antropófaga (2009) y Los amantes pasajeros (2013), hallamos un divertimento que nos remite al primer período de Almodóvar por el desenfado y la frescura manifestados, sin embargo, no serán abordados en este caso ya que los dejamos para un trabajo mayor en proceso.

Con respecto a los primeros films que abordamos presentan además la peculiaridad de tomar como punto de partida relatos literarios ajenos. La piel en que habito está basada en la novela Tarántula (Mygale, 2011), de Thierry Jonquet ${ }^{6}$. En el caso de Julieta, Almodóvar modeló su materia prima en base a tres relatos de Alice Munro": "Destino", "Pronto" y "Silencio" que forman parte libro Escapada ${ }^{8}$.

\section{Los abrazos rotos}

Gerard Genet utiliza el término transtextualidad para señalar: "todo lo que pone a un texto en relación, bien manifiesta o secreta, con otros textos" (Stam, Burgoyne, FittermanLewis, 1999, p. 235). De este modo, Stam y otros proponen nuevas categorías que suman al paradigma. Es así que definen el caso de la intratextualidad para definir "los procesos mediante los cuales las películas se refieren a sí mismas mediante estructuras especulares, microcósmicas y de mise-en-abyme" (Stam et al., 1999, p. 236). En el caso del film anali- 
zado, se está filmando un film dentro del film, lo que funciona como myse-en-abyme ${ }^{9}$, al tiempo que la venganza y el arrojar a la mujer por las escaleras se transforma en una suerte de situación especular al reduplicar la 'realidad' en el film que se está rodando. Otra de las categorías que mencionan los autores e incluyen como mecanismo transtextual, es la autocita. Ésta comprende las citas que un director efectúa de sus propias realizaciones. En el caso de Chicas con maletas remite al film Mujeres al borde de un ataque de nervios (1988), en el cual también se desarrolla el rodaje de una película del mismo nombre.

Almodóvar nos sorprende con Los abrazos rotos para utilizarlo como excusa para reflexionar acerca de la tarea del director cinematográfico, retomando la aproximación que había tenido al tema en la cinta anteriormente mencionada de 1988. El mundo del cine será nuevamente objeto de este acercamiento. Poe Lang señalaba:

El director nos lleva de la mano a sopesar ( ¿a mirar?) la importancia del montaje y a valorizar un viejo concepto de la teoría del cine, el concepto de fotogenia, en un film cuya materia principal es, quizás, la mirada (Poyato Sánchez, 2015, p. 152).

Este film se plantea, además, como un estudio sobre la mirada y, por qué no, sobre la ceguera. La mirada es el punto de partida del cine. Satisfacer la pulsión escópica del espectador, el punto de llegada.

Harry Cane es el seudónimo de un guionista de cine que ha quedado ciego. La gran paradoja que se presenta, ya que el cine es un arte que reside en la mirada. Del mismo modo que Woody Allen esbozase dicho contrasentido en Deconstruyendo a Harry (Deconstructing Harry, 1997). En aquel caso, Allen recurría a una mise-en-abime: en el film que se estaba rodando en la diégesis el director quedaba fuera de foco. La paradoja del personaje fuera de foco en Los abrazos rotos se verá llevada al extremo: ya no a partir de un defecto en la visión sino de la carencia de ésta. Cane narra, a retazos, las circunstancias que lo llevaron a dicha pérdida. De este modo, como en una suerte de relato enmarcado nos enteraremos, mediante un flashback, que en un principio su oficio fue el de director de cine. Durante el casting de Chicas con maletas, había quedado deslumbrado con Lena Martel, la esposa de un magnate. Habiendo contratado a la mujer como protagonista, se enamora profundamente de ella. El rodaje se convertiría de este modo en la excusa para los encuentros con su amada, burlando al marido celoso, a la sazón obsesionado con su joven y bella esposa. Otro de los tópicos que aborda Almodóvar parece girar en torno a que todos los seres humanos tienen su precio y todos sucumben ante el vil metal y la necesidad de afecto.

Lena, antes de convertirse en Magdalena Martel, era una acompañante escort y prostituta de lujo; ante la enfermedad de su padre, ayudada por su jefe económicamente, pasará de ser la secretaria del millonario a convertirse en su esposa.

Judit la montajista y amiga de Mateo Blanco, sucumbe ante la propuesta económica (o quizás, por celos y despecho) del empresario destrozando el montaje del film, por lo cual se transforma en un rotundo fracaso cinematográfico.

Ray X, el hijo de Enrique, anhelando las migajas de amor de su padre, se convierte en el espía de este, filmando clandestinamente la actividad de su madrastra en el set. Martel comprobará a partir de dichos registros que Lena lo desprecia y siente asco por él. El precio 
del muchacho no es, en este caso el dinero, sino el reconocimiento y amor paternos. Ante el fracaso para lograr ambos, se dedicará a destruirlo. Enamorado de Lena durante el rodaje, también será manipulado por la mujer, sin lograr siquiera unos mendrugos de amor. Uno de los temas candentes de este mundo globalizado lo constituye indudablemente el incremento de la violencia de género. Este problema sacude a nivel mundial. España no ha quedado al margen. Tal como señalara Marc Ferro aplicando la metodología de las ciencias sociales al abordaje de los films, existen agentes reveladores que hablan de una época, de una determinada sociedad, ya que: "su percepción, así como la de sus concordancia y discordancias con la ideología, es la que nos ayuda a descubrir lo latente bajo lo aparente, lo no visible a través de lo visible" (Ferro, 1995, p. 40). Creemos que la violencia de género da cuenta de ello. Más allá de la historia puntual que se narra, certifica la presencia de una situación preocupante para las sociedades contemporáneas.

En un ataque de celos, cuando Lena le comunica a su esposo que va abandonarlo, Ernesto Martel la arroja por las escaleras de su casa. La mujer no muere, pero enyesada debe permanecer en silla de ruedas y luego con muletas durante su convalecencia. Harry se apresura en reescribir las escenas del film que se está rodando, para ganar tiempo y conseguir prolongar la presencia de su amada en el set. Martel le permite a su esposa finalizar el rodaje bajo el juramento que Lena no lo abandonará, promesa que ella no cumplirá. De este modo, lo "real" se trasladará al film: en la ficción que se está rodando el personaje que interpreta Lena será arrojado por unas escaleras, lo que motivará el escayolado.

Con respecto a la juventud Diego, el hijo de la montajista, trabaja como secretario de Harry y, de noche, ayuda como DJ en un bar. Por error confunde su vaso ingiriendo drogas, lo que le producirá un coma. Notamos aquí que, si bien la representación de la juventud vuelve aparecer ligada a la noche y al consumo de estupefacientes, en esta etapa adquieren un sesgo distinto: ya no como divertidas integrantes de la noche madrileña, sino como riesgo potencial contra la salud de los jóvenes.

Las citas forman parte también de las estrategias intertextuales que habilitan las películas, adquiriendo visualización o bien verbalizadas tal como puntualizamos. En una escena de Te querré por siempre (Viaggio in Italia,1951) de Roberto Rossellini que aparece citada en el film, los protagonistas encuentran enterrada a una pareja que murió abrazada bajo la lava del Vesubio. Nuevamente el amor al cine y en especial al Neorrealismo italiano, formará parte nodal en la diégesis. Como la pareja de amantes a miles de años, Lena morirá besando a Mateo, sepultada bajo la lava que compone la superficie de la isla Lanzarote, último refugio de los amantes fugitivos (Poyato Sánchez, 2015).

Una cita plástica que no deja de llamar nuestra atención es la de Los amantes (1928), óleo del pintor belga René Magritte. Mucha tinta se ha derramado en torno a la interpretación del mismo: la pareja tiene el rostro cubierto por telas, sábanas quizás, y se besan a través de ellas. Con posterioridad, en 1984, el fotógrafo Robert Mapplethope realizaría su serie fotográfica White Gauze ${ }^{10}$, en la cual dos figuras humanas se hallan envueltas en vendas. En el film Lena y Ernesto mantienen relaciones debajo de las blancas sábanas, al besarse las imágenes seleccionadas vienen a nuestra memoria. Series de cuadros de Andy Warhol, de artistas de vanguardias y bodegones más tradicionales cubren las paredes de la casa, los cuartos y oficinas del millonario, mostrándonos una vez más el esmerado cuidado del director a la hora de crear atmósferas y asociaciones. 
Penélope Cruz es sin lugar a dudas la nueva Musa almodovariana. La cámara la ama, la acaricia, la adora. Durante el casting que se realiza en el interior del film, Pedro aprovecha para caracterizar a esta "chica Almodóvar" y, de la mano de su representación revivir a las grandes divas: Marilyn Monroe y Audrey Herpburn.

El personaje de Lena sufre, se desgarra, ama en silencio, toma decisiones. Sin embargo, no será suficiente para salir del laberinto de cristal que ella misma ha ayudado a cerrar.

Una conmovedora escena final nos revelará a Harry quien guiado por la voz de Ray X apoyará sus manos sobre la imagen proyectada en la pared que muestra el último beso que se dieran antes de su muerte, teniendo la certeza de que ése fue el sabor que se llevó a la tumba en sus labios. La imagen proyectada nos devuelve una suerte de granulado donde el hombre ciego ubica sus manos extendidas, en un desesperado intento de asir un minuto de nada.

\section{La piel en que habito}

Uno de los ingredientes del almodrama ${ }^{11}$ es la venganza. A veces atravesada por matices jocosos como en Mujeres al borde de un ataque de nervios (1988), otras veces con ribetes dramáticos como es el caso de La mala educación (2004). Nuevamente, es el motor que pone en funcionamiento el drama. Pero nos iremos dando cuenta de ello de a poco, ya que la información es suministrada a retazos, casi como los fragmentos de piel sintética que se van agregando dolorosamente al cuerpo de Vera. Si inicialmente sospechamos que la única venganza es la de la mujer cautiva, descubriremos que después de la violación de la hija de Robert se ha puesto en marcha un macabro plan de represalia que antecede a la primera situación. Con un guión basado en la novela Tarántula de Thierry Jonquet, Almodóvar nos hace testigos de lo acaecido. De este modo, las circunstancias se duplican, una vez más, en espejos invertidos y deformantes: Vicente en el pasado ha vejado a la hija de Robert y Zeca repetirá este acto vil con Vera, desconociendo quién es en realidad...

En Tarántula el nombre de la protagonista era Ėve, lo que inmediatamente remitía a la figura bíblica de Eva, sólo que en la novela de Jonquet no estaría creada a partir de la costilla de Adán sino del cuerpo entero de Vicent. Si las imágenes de transexuales habían aparecido a lo largo de la filmografía de Almodóvar, en el film que abordamos halla su carta de ciudadanía. Aquí se ha bautizado a la protagonista como Vera Cruz (¿la verdadera cruz, quizás?). En Metamorfosis Libro X, Ovidio (2012, pp. 181-183) narra la historia de un rey de Chipre, Pigmalión, quien permanecía soltero. Se había enamorado de una escultura de mujer, tallada en marfil, obra de su autoría. Tan hermosa era aquella y su apariencia tan real de suerte que: "La cara es la de una joven de verdad, creerías que está viva y que desearía moverse, si el recato no se lo impidiera. De tal manera el arte logra ocultar el arte", nos recordaba Ovidio. (op. cit, X - 250, p. 181) Lo cierto es que el joven cae profundamente enamorado del simulacro. Adorna su obra con hermosos ropajes femeninos y ricas joyas. La besa, la acaricia y le habla como si estuviese viva. Además, le llevaba regalos y la acostaba en la cama. Durante una fiesta dedicada a la diosa Venus, el rey elevó una plegaria: “'Si los dioses podéis conceder todo, deseo que mi esposa sea' (no se atrevió a decir "la joven de marfil") 'semejante a la de marfil'” (op. cit., X - 275, p. 182). De regreso a su hogar, al besar los marmóreos labios le pareció que éstos están cálidos, al tocar su piel notó que cedía bajo sus dedos. Con mezcla de temor y sorpresa el joven observó azorado cómo su estatua cobraba vida, al tiempo que la doncella se ruborizaba por la efusividad de su enamorado. 
Venus celebra entonces las bodas de la feliz pareja. Fernández Corte y Cantó Llorca nos advierten que en el imaginario antiguo y, en especial en el ovidiano, el mito encierra una nota incestuosa ya que se consideraba a las obras de arte (pinturas, esculturas, etc.) como hijas del artista que las había concebido (op.cit., X, p. 183).

Como Pigmalión, el cirujano Robert Ledgard revivirá a su esposa muerta, creando su propia Galatea, moldeando un cuerpo transexual que se alzará como expresión de su venganza y recordatorio de su deseo. La historia encierra altas dosis de perversión: la imagen de su difunta esposa rediviva, la operación transgénero del violador de su hija -sin su consentimiento-, el encierro y reclusión de la "muchacha" en el Cigarral -a la sazón hogar del facultativo-, el maltrato del médico hacia su prisionera y esa suerte de amor-repulsión que experimenta hacia ella.

La violación constituye un tema recurrente a lo largo de la filmografía del director analizado, ha aparecido en Pepi, Luci, Bom y otras chicas del montón (1980), Átame (1989), Kika (1993), La mala educación (2004) y Volver (2006), tanto visualizada como en los diálogos de los personajes. Además, en Átame, Ricky secuestraba a Marina a fin de que ella se enamorase al conocerlo. Nuevamente aquí aparece el tema de la privación de la libertad, sólo que aquí se produce para consumar una terrible venganza. Para sobrevivir el muchacho secuestrado desarrolla sentimientos encontrados hacia su captor, producto del Síndrome de Estocolmo: Vicente es reducido, en una primera etapa, a una animalidad absoluta.

La violación de la hija será rememorada por el padre y luego por Vera/Vicente, desde dos puntos de vista diferentes y contrapuestos. El segundo relato aportará más información. Norma ha asistido a una fiesta de casamiento junto a su padre. Allí conoce a Vicente. El muchacho ha ingerido drogas tal como le comentara a la joven, que al ser paciente psiquiátrica le recita qué ha ingerido ese día. La pareja recorre el jardín buscando un lugar para intimar. Sin embargo, Norma vuelve a la realidad violentamente al escuchar la música que cantaba en el momento del suicidio de su madre. Enloquecida por ello, comienza a forcejear con el joven, que termina golpeándola, lo que produce su desvanecimiento. Al despertar en brazos de su padre que trata de volverla en sí, la joven cree que éste fue el responsable de su violación, quedando en un estado severo de alteración. Sin embargo, muchos de los datos que nos suministra este segundo flashback responde más a la omnisciencia del director como narrador privilegiado que a la percepción de Vicente.

Antes de consumar relaciones la pareja ha salido al jardín, allí vemos y escuchamos cómo un grupo de jóvenes narra que han consumido drogas, por ello señalamos la imposibilidad del joven de haber sido testigo de algunos datos que se suministran. Norma y Vicente se desplazan por el camino. La cámara en plano general panea lateralmente descubriendo ante nuestros ojos parejas de jóvenes separados por escasos metros de distancia. Se encuentran completamente desnudos. Todos están manteniendo relaciones sexuales. Almodóvar nos muestra una libertad sexual que sólo los jóvenes parecen poder permitirse. Estas imágenes nos remiten indudablemente al cine de la primera época del director manchego. Posteriormente Vera será víctima de estupro en manos de Zeca. Desplazado de su lugar de socialización como hombre, Vicente ha experimentado, lo que implica una vejación, sólo que esta vez en carne propia. Vera es el producto de la terrible vendetta que Robert ha ideado, a pesar de que, la violación de la fémina en manos de su propio hermano, no figuraba en sus planes. 
En discrepancia con la novela de Jonquet, en la película, Vicente ha sido el único responsable, sin embargo, en el relato literario la gran revelación será la participación de Alex, el amigo del joven, en tan vil accionar.

Nuevamente el destino jugará una mala pasada. Como Caín y Abel, Robert asesinará a Zeca, sin sospechar que era más lo que los unía que lo que los separaba.

Mencionamos con anterioridad operaciones de intertextualidad. Algunos de los encuadres del film parecen rememorar fotografías de Robert Mapplethorpe, de este modo, el cuerpo de Vera desnudo recortado en un plano que abarca desde el cuello hasta más abajo del pubis. Esta imagen remite, indudablemente, a la serie de Lydia Cheng (1985) ${ }^{12}$; asimismo, el primer plano de Marilla observando la violación de Vera a través del monitor, nos devuelve la visión de la mujer recortada sobre fondo oscuro, concebida como el retrato de Doris Saatchi $(1983)^{13}$. No debe extrañarnos la abierta cita al fallecido y controversial fotógrafo, ya que Almodóvar le profesa admiración ${ }^{14}$.

El desarrollo de materiales e insumos para cirugías ha proliferado en los últimos tiempos. Los cirujanos plásticos utilizan marcadores quirúrgicos para trazar líneas y patrones para marcar las zonas antes de realizar incisiones durante las operaciones. En el film, los trazos aparecen primero sobre el maniquí, por medio de un fundido encadenado pasamos al cuerpo de Vera ubicado en la misma posición y con las mismas marcas que connotan las imágenes de los mapas de cortes vacunos que se exhiben en las carnicerías.

Los planos detalle nos muestran la meticulosidad con la que trabaja el facultativo, reconstruyendo a retazos los tejidos dañados. No podemos menos que pensar en el sintomático caso de Frankenstein de Mary Shelley cuyo protagonista, el doctor Víctor Frankenstein, un científico obsesionado con los secretos de la vida y la muerta, da vida a un ser monstruoso creado a partir de partes de cadáveres. También en nuestro caso, Vera parece creada a retazos... Si a todo ello sumamos el conocimiento que vamos adquiriendo a lo largo del relato acerca de la experimentación en el campo transgénico que realiza el Dr. Ledgard, el cuerpo de la mujer se va constituyendo en un campo de experimentación. De hecho, Gal, la piel transgénica -que tiene ese nombre en homenaje a su difunta esposa-, parece soldarse con el calor al cuerpo humano. Aquella emite un aroma diferente -señala Ledgard-por lo que la hace inmune al mosquito de la malaria, por ejemplo. Sin embargo, a mayor resistencia que adquiere la piel, se visualiza menor sensibilidad en el sujeto portador como podemos apreciar en la escena en la que Robert le promete a Vera que ya no habrá más quemaduras. Robert ha jugado a ser Dios, tal como se lo señala el presidente del Instituto de Biotecnología, ya que ha cruzado células humanas con animales para lograr mayor dureza.

El universo almodovariano de este último período se halla poblado de mujeres que son consecuentes con sus deseos, pero a veces prisioneras de malas jugadas del destino o de elecciones que repercuten en su presente.

Gal, la fallecida esposa de Legard, fue amante de Zeca. Decididos a fugarse fueron sorprendidos por un accidente automovilístico: el hombre salió indemne, la mujer no tuvo tanta suerte. Quemada totalmente sufrió hasta lo indecible, motivo por el cual su marido se obsesionó trabajando día y noche para encontrar el modo de reparar los tejidos dañados. Marilla, ha pasado toda su vida al lado del facultativo, ha callado que es la madre biológica de Robert y Zeca, si bien de niños jugaban juntos. Como si se tratase de la filosofía de Rosseau que concebía que el hombre no nacía ni bueno ni malo sino que se hacía en función 
de las circunstancias, Almodóvar parece hacerse eco de ello: Robert ha sido educado por la familia Ledgard como hijo propio y ha alcanzado una posición encumbrada dentro de la sociedad, por el contrario Zeca se ha educado en Brasil, en una favela y, desde los siete años, transportaba drogas en el interior de la misma, situación que su madre calló en su momento sin tratar de revertirla.

Norma, la hija del cirujano, ha sido testigo del suicidio de su madre. Ello la ha llevado a una situación de institucionalización en un sanatorio psiquiátrico. Cuando presenta una leve mejoría experimenta en una fiesta atracción por Vicente. Consienten en tener relaciones, pero en el momento en que suena la música, la melodía la retrotrae al momento de la muerte de su madre, sacándola de quicio. El muchacho la golpea, dejándola inconsciente. La violación es llevada a cabo. Al volver la joven en sí, creerá que ha sido su padre el responsable del estupro, entrando en una profunda crisis que la llevará a repetir la historia de su madre al suicidarse. Por tal motivo Ledgard moverá su más implacable venganza. Vera aparece como una mujer sufriente, muy bella. Los primeros planos de su rostro nos permiten presenciar una sensibilidad a flor de piel. No sabemos por qué Robert la maltrata, la droga o la rechaza, hasta que la verdad parece estallar ante nuestros ojos: la violación que cometió años atrás como Vicente, no ha quedado impune...

Con respecto a la juventud aparece retratada como desenfrenada. Las drogas y el sexo son presentadas como naturales, así como una libertad sexual asociada a ellas.

Las citas a artistas plásticos proliferan en los films del director. La joven prisionera escribe las paredes de su cuarto, lo que a primera impresión remite a Louis Bourgeois. Además, hay una cita explícita a dos cuadros de Tiziano que representan a Venus. Legard observa a su diosa a través de una pantalla jugando a ser dios ampliando las imágenes femeninas con sólo activar el botón de un control remoto (Poyato Sánchez, 2015, pp. 108-110). Como las Venus de Tiziano, Vera se entrega a la mirada masculina, sabe que está siendo observada y deseada por su hacedor. Sin embargo, la mujer adquiere anclaje carnal en la mente del cirujano luego del estupro. Las relaciones entre el doctor y su prisionera se modificarán a partir de este momento.

La muerte del cirujano libera a la joven cautiva, que volverá a la tienda de ropa para reunirse con sus seres queridos: tres años después de su desaparición y como Vera, ya no como Vicente.

\section{Julieta}

Una vez más el director se centra en una historia marcada por el dolor y la pérdida, tópicos que aparecen en mayor o en menor medida en sus creaciones.

Julieta tiene planeado un viaje a Portugal junto a Lorenzo, su pareja. Observamos preparativos, objetos que se embalan. Y un silencio. Cosas del pasado de las que no se habla, que se desconocen, se ocultan, pero que acechan.

El encuentro entre Julieta y Beatriz, la amiga de Antía -su hija- será crucial. Después de doce años tendrá la primera pista del paradero de su hija. Se produce aquí el primer punto de giro del relato: Julieta rompe con su novio y se dedicará en cuerpo y alma a escribirle a su hija. Narrará su historia, exorcizará sus propios demonios, en una suerte de libro/diario destinado a Antía. 
Almodóvar hace desfilar ante nuestros ojos a una Julieta joven, especialista en filología y excelente docente de nivel medio, que se enamora de un pescador, Xoan con quien tendrá una hija. De este modo y, tal como sucede en los tres relatos de Alice Munro, la cotidianeidad invadirá la pantalla. Sin estridencias ni grandilocuencias.

La pérdida parece haber sido el motor de la vida de la protagonista: primero Xoan, víctima de una tormenta fatal cuya existencia se ha cobrado un mar embravecido y luego, Antía, quien, tratando de ayudar a su madre a sobrellevar el trance, se ha perdido a sí misma y su fe. La búsqueda de la joven la llevará a una secta, sitio en el que Julieta perderá su rastro.

Las mujeres que retrata el director manchego sufren, pierden, recuperan, luchan por el amor, por sus ideales. La adolescencia de Antía ha sido muy dura: ante la crisis de su madre por la pérdida del marido, la jovencita asume el papel de un adulto apuntalando a su progenitora. Esta inversión de roles la socava profundamente, distanciándose no sólo de su mejor amiga, sino también cortando de lleno con el mundo que la rodeaba.

Un detalle curioso puede plantearlo el hecho de las diferentes clases sociales a las que pertenecen ambas niñas. Bea es de una clase más acomodada, motivo por el cual, luego de su pérdida Julieta se traslada a la casa de la amiga de su hija para cambiar de ambiente y cuidar a las niñas durante el verano ante la ausencia de los dueños de casa. Si sospechamos inicialmente en un deslumbramiento por los bienes materiales por parte de Antía, descubrimos luego que no es así. Que esa especie de desasosiego que percibimos responde a los sutiles cambios actitudinales que va manifestando el personaje y que el director registra con la cámara, lo que se verá confirmado por el testimonio de una Bea adulta en el casual encuentro con Julieta. Será preciso deconstruir la imagen que nos habíamos forjado de la jovencita para confrontarla con la real ficcional y, a partir de ello, comprender el porqué del abandono de su mundo y sus afectos.

En un segundo encuentro azaroso Beatriz le revelará que su hija vive en las cercanías del lago Como, que se ha casado y tiene tres hijos.

El estilo de Almodóvar, cada vez más sereno, en apariencia, muestra y oculta, revela y sugiere. Crea climas. Escruta sentimientos, exhibe miserias... Nos hace sentir en carne propia la espera de la madre por su hija, que en doce años no llegó nunca a un festejo de cumpleaños, enviando sólo una tarjeta de salutación. Doce en total, número que, seguramente es sinónimo de infinito, especialmente para esa madre que espera.

Las mujeres que pueblan sus encuadres no sólo sufren, también establecen extraños lazos de amistad. Julieta traba amistad con Ava, una joven escultora amiga de Xoan. Las esculturas eróticas de ella ponen un toque almodovariano a la iconografía del relato.

Aquejada por un cáncer terminal, perderá la vida, no sin antes revelarle detalles del accionar de la hija, que echará luz al oscuro camino de búsqueda de la madre. Julieta las culpaba de la pérdida del padre y, cuando se incluyó a sí misma en este círculo de culpa, huyó.

Resulta sintomático que la mención al cáncer aparece en dos ocasiones a lo largo del film. Para referir el final de la escultora y para ubicarnos en la enfermedad que tenía postrada a la madre de Julieta. Dos mujeres. Idéntica enfermedad.

La infidelidad también se hace presente en el film. El padre de Julieta le ha sido infiel durante la convalecencia a la madre de la mujer, con Sanaa, la cuidadora de la enferma. Julieta descubrirá que, durante su ausencia, al haber ido a visitar a su madre, Xoan le fue infiel con Ava. 
Curiosamente, parecería que sólo los hombres son capaces de ser infieles. Los hombres traicionan. Las mujeres son fieles. Sufren, enferman, mueren.

\section{A modo de cierre}

Lejos de concluir el visionado de los films disparan en nuestra mente relaciones, cruces y reflexiones.

La juventud de la primera época de Almodóvar ya no escandaliza, ha madurado. Sin embargo, sigue disfrutando de una libertad sexual plena. Dudamos que ello sea lo que sucede en toda la Península Ibérica, más bien, parece el reflejo de las zonas metropolitanas. El consumo de drogas caracterizaría también a sus jóvenes, sobre todo en relación a la vida nocturna y la música, pero el director parece querer advertirnos que, como contrapartida, pueden resultar peligrosas.

Indudablemente las películas analizadas se hallan protagonizadas por personajes femeninos que sufren. Ellas son consecuentes con sus deseos. Logran sus objetivos. Son madres, hijas, amigas. Sufren abandonos. Son víctimas de violencia de género. Enferman. Sufren carencias. Sin embargo, son capaces de dar batalla. No dan lástima. Se levantan, salen adelante sin importar lo que cueste. Sacan fuerzas del mismo dolor. No engañan, son engañadas.

En los tres films abordados el cuerpo de la mujer se presenta fragmentado, seccionado: desde las fotos destruidas de Julieta y Los abrazos rotos, pasando por las imágenes del cuerpo de Lena, examinado a través de las diversas radiografías que dan cuenta de sus fracturas hasta el cuerpo marcado de Vera en el quirófano de La piel en que habito. Como si fuese un rompecabezas que se va armando, que se disecciona.

Sostiene Marc Ferro: "Al interpretar un papel activo contrapuesto a la historia oficial, el cine se convierte de este modo en un agente de la historia y puede motivar una toma de conciencia." (Ferro, 1995, p. 17) Es de este modo que el cine de Almodóvar se convierte en una suerte de contrahistoria, ya que se opone en cierta medida a la historia oficial al negarle en sus diégesis la existencia a Franco o al contar avatares de la movida o al presentar putas, travestis, transexuales, drogadictas, masoquistas, asesinas y dark queens. A partir de sus films podemos leer también problemáticas que inquietan, que preocupan a la sociedad, que buscan tomas de posición. El sida, el cáncer, el asesinato, la infidelidad, la violencia de género, el cuerpo transgénero, lo poshumano. Como un vasto abanico de posibilidades Almodóvar muestra, escruta, investiga, expone, pero no juzga, la tarea intelectual queda delegada al espectador que una vez más se emociona ante la profundidad hermeneútica y visual del almodrama.

\section{Notas}

1. El subrayado es nuestro.

2. Su contacto con el cine es tardío debido a que en el pueblo que habitaba no había salas de exhibición cinematográficas (Méjean, 2007, p. 16). 
3. García Curado, A. (2002). ¡Qué tiempos aquellos, coño! Cincuenta años de aletargada sexualidad. Madrid: Edaf.

4. Esta periodización corresponde a Héctor Fouce Rodríguez y difiere de la suministrada por Javier Escudero quien la ubica entre 1977 y 1983.

5. Para profundizar el análisis de la filmografía de esta etapa remitimos al trabajo anteriormente citado (Balán y Gruber, 2009).

6. Jonquet, Thierry (París 19/01/1954 - Ibídem 09/08/2009) escritor francés, autor de novelas negras. Fue miembro de la Liga Comunista revolucionaria.

7. Munro, Alice Ann (Wingham, Canadá 10/07/1931) cuentista canadiense, considerada una de las escritoras más destacadas de lengua inglesa. Ganadora del Premio Nobel de Literatura en el año 2013.

8. A la sazón, en la primera secuencia de La piel en que habito, cuando Marilla le facilita a través del montaplatos comida y otros objetos a Vera, el libro Escapada de Alice Munro integra el conjunto de enseres constituyéndose de este modo, en una cita visual del director manchego.

9. "Mise en abîme: (...) Es un procedimiento que consiste en incluir en la obra (pictórica o literaria) un enclave que reproduce algunas de sus propiedades o similitudes estructurales. El reflejo de la obra externa en el enclave interno puede ser una imagen idéntica, invertida, multiplicada o aproximada.

El teatro en el teatro es la forma más corriente de la mise en abîme. (...)” (Pavis, P., 1990, p. 316).

10. http://www.mapplethorpe.org/exhibitions/2016-11-02_galleria-franco-noero/

11. "Nominado 'almodrama' por Silvia Colmenero, se trata en todo caso de un melodrama manifiestamente corporal donde el deseo es sistemáticamente vinculado al dolor, la pérdida y la muerte. Con el almodrama cristaliza, si no el mejor, sí el Almodóvar más elaborado" (Poyato Sánchez, 2015, p. 102).

12. http://www.mapplethorpe.org/portfolios/female-nudes/?i=1

13. http://www.tate.org.uk/art/artworks/mapplethorpe-doris-saatchi-ar00155

14. La galería Elvira González abrió sus puertas del 7 de junio al 22 de julio de 2011 para exhibir 28 fotografías de Robert Mapplethorpe. La tarea de curaduría estuvo a cargo de Pedro Almodóvar.

\section{Bibliografía}

Balán, M. y Gruber, M. (2009). "La construcción de la imagen femenina en los films de Pedro Almodóvar" en XII Jornadas Interescuelas / Departamentos de Historia, Departamento de Historia, Facultad de Humanidades y Centro Regional Universitario Bariloche. Universidad Nacional del Comahue, San Carlos de Bariloche.

Balán, M. y Gruber, M. (2010). "La construcción de la imagen femenina en los films de Almodóvar" en Actas del II Congreso de ASAECA - Buenos Aires, 2010 / edición literaria a cargo de Marcela Visconti y Malena Verardi. - 1a ed. - Ciudad Autónoma de Buenos Aires: ASAECA. 
Britto García, L. (1990). El imperio contracultural del rock a la postmodernidad. Nueva Sociedad.

Escudero, J. (1998). “Rosa Montero y Pedro Almodóvar: miseria y estilización de la movida madrileña" en Arizona Journal of Hispanic Cultural Studies, vol. 2, pp. 147-161.

Ferro, M. (2008). El cine, una visión de la historia. Madrid: Akal.

Ferro, M. (1995). Historia contemporánea y cine. Barcelona: Ariel.

Fouce Rodríguez, H. (2002). "El futuro ya está aquí" música pop y cambio cultural en España. Madrid 1978-1985. Tesis doctoral. Madrid: Universidad Complutense de Madrid.

García Curado, A. (2002). ¡Qué tiempos aquellos, coño! Cincuenta años de aletargada sexualidad. Madrid: Edaf.

Garrido, E. (Ed.) (1997). Historia de las mujeres en España. Madrid: Síntesis.

Holguín, A. (1999). Pedro Almodóvar. Madrid: Cátedra.

Méjean, J. M. (2007). Pedro Almodóvar. Bs. As.: Manontroppo.

Ovidio Nasón, P. (2012). Metamorfosis. Libros VI - X., trad. Fernández Corte, J. C. y Cantó Llorca, J. Madrid: Gredós.

Poyato Sánchez P. (Ed.) (2015). El cine de Almodóvar. Una poética de lo "trans". Sevilla: Universidad Internacional de Andalucía.

Ribas, J. (2007). Los 70 a destajo. Ajoblanco y libertad. Bs. As.: Emecé.

Stam, R., Burgoyne, R., Flitterman-Lewis, S. (1999). Nuevos conceptos de la teoría del cine. Estructuralismo, semiótica, narratología, psicoanálisis, intertextualidad. Barcelona: Paidós.

Strauss, F. (2001). Conversaciones sobre Pedro Almodóvar. España: Akal.

\begin{abstract}
The times after General Franco's death, in Spain, were characterized for the relaxation of sexual censorship ("el destape español"). Each and everything, for so long forbidden, would make a rampant entrance into people's daily life, and it wouldn't take long before being captured by the cinematographic screen. In this way, "showing" and "telling" everything that couldn't be revealed before due to the exclusion and prohibition, became the key of many cultural creations of that moment.

The 80's would salute "La Movida", a designated environment for artists. Pedro Almodóvar would be part of it. He didn't have a cinematic academic education, but he quickly became one of the referents of the young Spanish cinema. After a stage of provocative manifestation, his cinema reached a formal maturity that coincided with his international projection. In this way, he entered both, the American and Latin-American markets, and harvested nominations, awards and general acknowledgement.

He has been identified, by some authors, as the filmmaker that better represents women, considering that his films embody a highly personal image of the feminine soul. He detached himself of the mass media and Francoism stereotypes, and in his works he portrays a plural construction of the "weaker sex" and the image of youth.

Our goal, in this work, is to analyze his latest filmworks -Los abrazos rotos (2009), La piel que habito (2011) and Julieta (2016) - aiming at meditating on the women in his frames, the way in which he represents young people and their problematic, as well as the reasons
\end{abstract}


behind his particular formal and aesthetic treatment. This leads us to ask ourselves if we can consider the existence of an "Almodovar's style".

Key words: cinema - representation - feminine image - youth - author.

Resumo: O tempo posterior à morte do geral Franco na Espanha se caracterizou pelo destape. O proibido pelo regime durante tantos anos estourou na vida cotidiana e se plasmou no cinema. Assim, mostrar e dizer tudo aquilo que tinha sido excluído e proibido se transformou na chave de muitas criações culturais desse momento.

Os anos '80 trouxeram a Movida Madrilena, lugar de reunião forçoso para o ambiente artístico. Pedro Almodóvar foi um dos integrantes. Sem formação acadêmica cinematográfica, rapidamente se converteu num referente do jovem cinema espanhol. Depois duma etapa provocativa, seu cinema alcançou uma maturidade formal coincidente com sua projeção internacional. Deste modo, ingressa no mercado estadunidense e latino-americano, obtendo nominações, prêmios e reconhecimento.

Definido por alguns autores como o cineasta que melhor representa às mulheres, se considera que seus filmes plasmam uma visão pessoal da alma feminina. Liberado dos estereótipos próprios dos meios de comunicação e do franquismo, manifesta em sua obra uma construção plural da imagem do "sexo débil" e da juventude.

Este trabalho analisa os últimos filmes do diretor: Os abraços rotos (2009), A pele que habito (2010) e Julieta (2016), para refletir sobre as mulheres que representa, o modo no qual representa aos jovens e suas problemáticas, assim como os motivos deste particular tratamento formal e estético. Isto faz perguntar sobre a existência de um "estilo Almodóvar".

Palavras chave: cinema - representação - imagem feminina - juventude - autor. 